\title{
ArcheoSciences
}

Revue d'archéométrie

33 (suppl.) | 2009

Mémoire du sol, espace des hommes

\section{Ten years on: Geophysical survey on the 'Heart of Neolithic Orkney' World Heritage Area}

S. M. Ovenden, J. Gater and M. K. Saunders

\section{(2) OpenEdition}

1 Journals

\section{Electronic version}

URL: https://journals.openedition.org/archeosciences/1422

DOI: 10.4000/archeosciences. 1422

ISBN: 978-2-7535-1599-4

ISSN: 2104-3728

Publisher

Presses universitaires de Rennes

\section{Printed version}

Date of publication: 30 October 2009

Number of pages: $125-127$

ISBN: 978-2-7535-0943-6

ISSN: $1960-1360$

\section{Electronic reference}

S. M. Ovenden, J. Gater and M. K. Saunders, "Ten years on: Geophysical survey on the 'Heart of Neolithic Orkney' World Heritage Area", ArcheoSciences [Online], 33 (suppl.) | 2009, Online since 30 October 2011, connection on 01 February 2022. URL: http://journals.openedition.org/archeosciences/ 1422 ; DOI: https://doi.org/10.4000/archeosciences.1422 


\title{
Ten years on: Geophysical survey on the 'Heart of Neolithic Orkney' World Heritage Area
}

\author{
S. M. Ovenden*, J. Gater** and M. K. Saunders*
}

Key words: Magnetometry, World heritage, Landscape, Orkney, Multiphase.

2009 marks an important landmark in the use of geophysical survey on Orkney, as it is now 10 years since the first work was undertaken on the Heart of Neolithic Orkney World Heritage Area. This work began with a gradiometer survey of a few fields around the Stones of Stenness in 1999, which evolved into the WHA Inner Buffer Zone project in 2002. By 2009 the area investigated has expanded to cover almost 300 ha of detailed gradiometer survey. Data has been collected at $1 \mathrm{~m}$ by $0.25 \mathrm{~m}$ intervals with initially Geoscan FM36s and in more recent years with Bartington Grad 601-2 systems. In addition limited amounts of area resistance (Geoscan RM15), ground penetrating radar (GSSI Sir 3000) and electrical imaging (IRIS Syscal Pro) have been undertaken on selected targets. Although surveys of this size have been done before, this Orkney work is important for a number of reasons, not least because it covers the full extent of the designated WHA Inner Buffer Zone and thus offers a very complete picture of this area, aiding its management and conservation.

Although the designation of Orkney's WHA refers to its Neolithic monuments, little was known about the area beyond the existence of a number of extant monumental structures. Questions arose as to the role that these sites played in the landscape and how they interacted with it. Beyond the excavations of Barnhouse and Skara Brae to the north-west, little was known about domestic activities within the area and how these related to the large monumental sites.

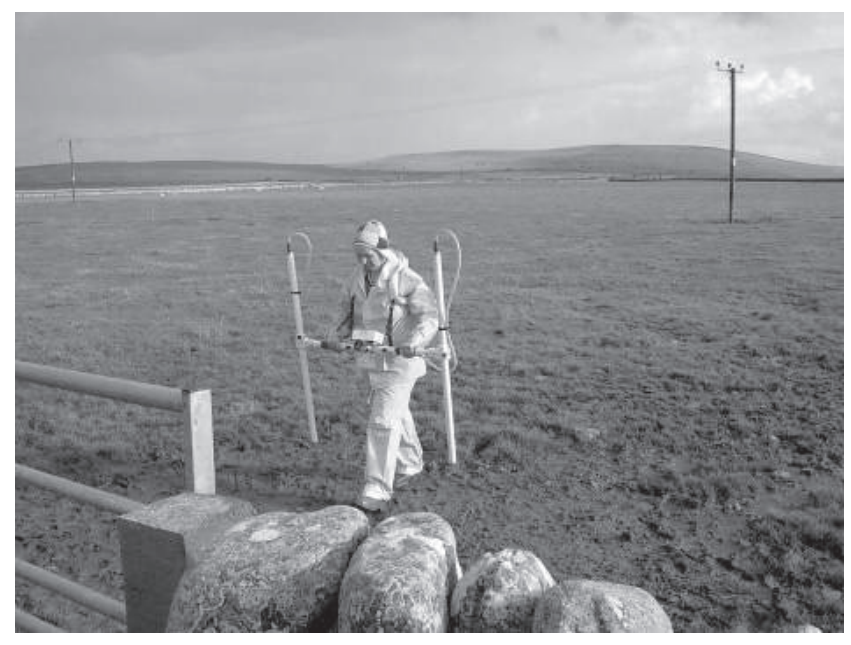

Figure 1: Amanda Brend undertakes gradiometer survey as part of WHA Phase XI in October 2008.

Ten years on, many of these questions appear to have been answered and the WHA is a landscape now much better understood. It is clear that, although famous for its Neolithic sites, the WHA was, in fact, an evolving area producing evidence of fairly large-scale activities in later periods such as the Iron Age (cf. Big Howe and Skaill brochs) and medieval periods (extensive ridge and furrow cultivation and evidence of possible farmsteads). In some areas the survey found nothing, which is interesting because this reinforces

* Orkney College Geophysics Unit, Orkney College, East Road, Kirkwall, KW15 1LX, UK. (Susan.ovenden@uhi.ac.uk)

** GSB Prospection Ltd, Cowburn Farm, Market Street, Thornton, BD13 3HW, UK. 


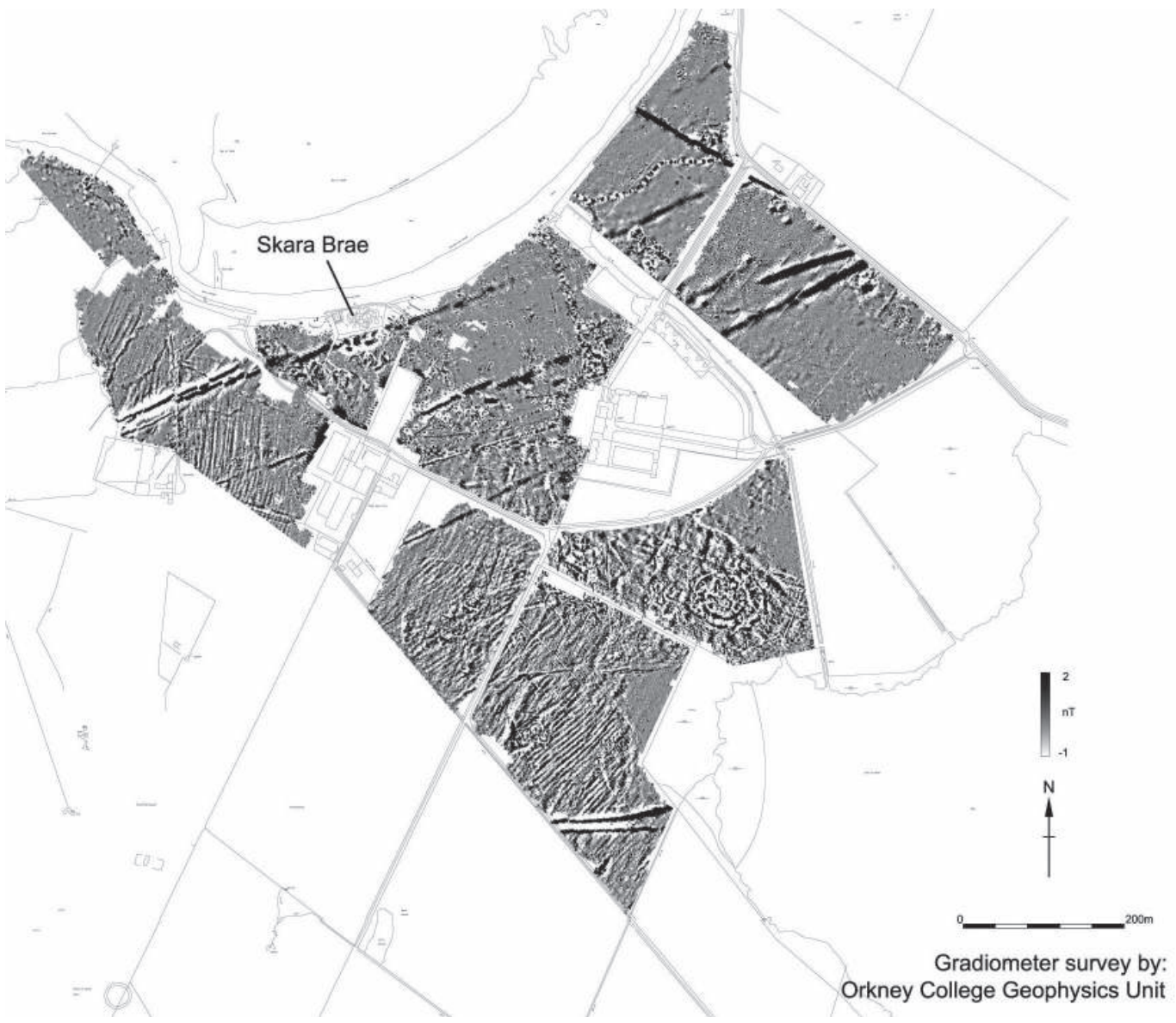

Figure 2: The extent of the Heart of Neolithic Orkney WHA survey as of November 2008. the idea of a clear demarcation between a 'domestic' and a 'ceremonial' landscape. In other places, huge sites, completely absent from our current archaeological records, have been rediscovered. What is perhaps most important is the way in which sites in the WHA no longer sit in isolation; instead they can be interpreted in context and this can only add to our understanding and management of the area.

After ten years, geophysical survey is almost complete over the Heart of Neolithic Orkney WHA, but in many ways the project is only just beginning. This poster will look at the large and interesting dataset that now lies at our disposal and at the careful consideration which must be given to how this data should best be used. One main priority is to obtain topographic information for the area through the use of LiDAR survey, hopefully being undertaken during 2009/10. This data should significantly enhance the interpretation of the geophysical survey, but also help us to understand how topographic features were used and exploited during prehistory. Another possibility discussed will be the creation of some kind of integrated dataset, generated using the information already held for the WHA, in which geophysical and topographic data would form a large part. We are very aware that Orkney is distant from many places and such a system could form the basis of a web-based interface to allow researchers from all over the world access to this data.

Further consideration will also be given as to how best this useful resource can best be used to inform our archaeological understanding of the WHA Inner Buffer Zone. In Britain, aerial photography has been used as a tool for the interpretation and understanding of how landscapes were used, a stage beyond the mere classification of monument types. Perhaps this project offers a valuable opportunity to approach geophysical survey in a similar manner and use it to make informative statements on the changing nature of an extremely important archaeological landscape. 


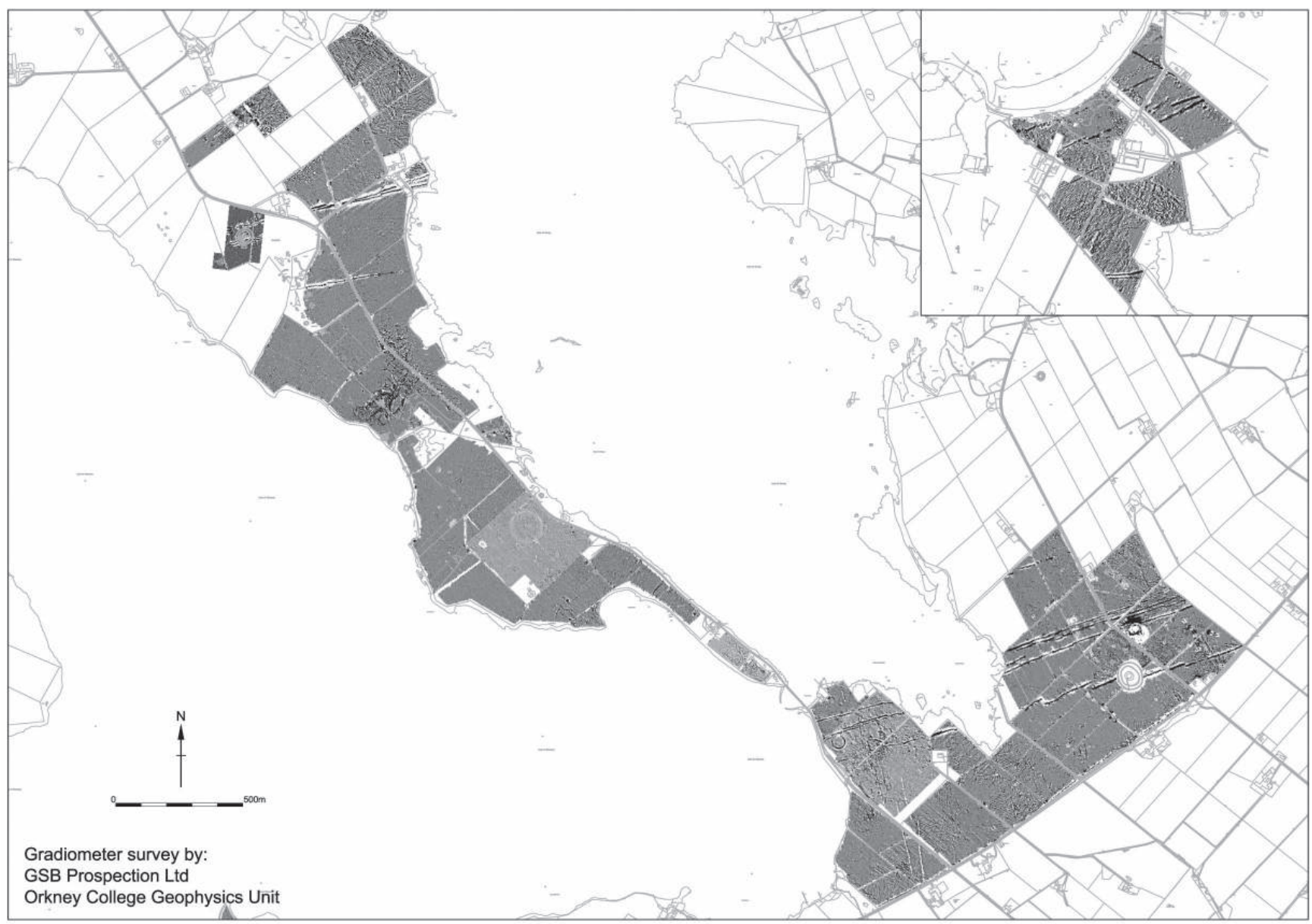

Figure 3: Geophysics begins to place Skara Brae in a landscape context. Neolithic, Bronze Age, Iron Age, Medieval and modern activities are all evident in this area.

\section{References}

Card, N., Downes, J., Gibson, J. and Ovenden, S., 2007. Bringing a landscape to life? - researching and managing the 'The Heart of Neolithic Orkney' World Heritage Site. World Archaeology, 39-3.

Card, N., Cluett, J., Downes, J., Gater, J. and Ovenden, S., 2007. Heart of Neolithic Orkney World Heritage Site: Building a landscape. In Larsson, M., Parker Pearson, M. (dir.). From Stonehenge to the Baltic: Living with Cultural Diversity in the Third Millennium BC, Brit Arch Report Inter Series 1692, 221-231.
Downes, J., Forster, S. M., Wickham-Jones, C. R. and Callister, J., 2005. The Heart of Neolithic Orkney World Heritage Site Research Agenda. Historic Scotland, Edinburgh.

GSB Prospection 1999-2004. Orkney World Heritage Area; Unpublished Reports.

Historic Scotland, 1998. Nomination of the Heart of Neolithic Orkney for Inclusion in the World Heritage List. Historic Scotland. Unpublished document submitted to UNESCO.

OCGU 2004-2009. Orkney World Heritage Area; Unpublished Reports. 